\title{
KMT5A wt Allele
}

National Cancer Institute

\section{Source}

National Cancer Institute. KMT5A wt Allele. NCI Thesaurus. Code C73665.

Human KMT5A wild-type allele is located in the vicinity of 12 q24.31 and is approximately $26 \mathrm{~kb}$ in length. This allele, which encodes N-lysine methyltransferase KMT5A protein, is involved in protein methylation and chromatin modification. 